Article

\title{
Corporate Social Responsibility, Trade Credit and Financial Crisis
}

\author{
Asif Saeed ${ }^{1,2, * \mathbb{D}}$ and Qasim Zureigat ${ }^{3}$ \\ 1 IRG, University Paris-Est Creteil, 94010 Creteil, France \\ 2 FSM, National University of Computer and Emerging Sciences, Lahore 54000, Pakistan \\ 3 Sulaiman AlRajhi School of Business, Sulaiman AlRajhi University, Al Bukariyah 51941, Al Qassim Province, \\ Saudi Arabia; q.zureigat@sr.edu.sa \\ * Correspondence: asif.saeed@outlook.com; Tel.: +92-3336309789
}

Received: 31 May 2020; Accepted: 24 June 2020; Published: 3 July 2020

check for updates

\begin{abstract}
Socially responsible firms receive more finance and have been well researched in the corporate finance literature. In this paper, we examine the relationship between CSR and trade credit. Using data from the US manufacturing industry, we find that CSR has a significant positive association with the buyer and supplier sides of trade credit. During the 2008-2009 financial crisis, the manufacturing industry trade badly fell. We also argue and find evidence that, during crisis, CSR is negatively associated with trade credit. These findings are robust for alternate proxies of CSR and trade credit, sample selection, and time period. Moreover, the potential endogeneity concerns do not affect our results. Finally, we show that this relationship exists for both domestic and multinational firms' subsamples. Overall, our results indicate that firms with high social performance use more trade credit to increase their business activity.
\end{abstract}

Keywords: corporate social responsibility; trade credit; crisis; multinationals

\section{Introduction}

Corporate social responsibility (CSR) has gained vital importance in the last few decades. In 2015, Microsoft employees donated USD 125 million to 18,000 schools and nonprofit organizations across the world as community philanthropic programs. Trisa Thompson, Dell's chief responsibility officer, provides her view on why commitments to sustainability will not waiver: "Completely regardless of the global political environment, corporations will continue the march toward sustainable production because it makes sense and is a business necessity". Thompson also said: "We are seeing an increase in sustainability and social responsibility show up as a weighted factor in RFPs (Request for Proposals), particularly from European Governments". A growing number of firms spend plenty of resources and time on CSR-supporting activities to attract socially responsible investors, for a firm's good image, and for the interests of potential customers and employees. CSR investment has a two-fold objective: on the one side they are showing their commitment to the betterment of community and environment, and on another hand, they improve firm performance through socially responsible investments. Large films demonstrate an especially exceptional commitment to CSR. For example, CVS pharmacy bore a USD 2 billion loss by stopping sales of cigarettes in their marketplace (Adhikari 2016).

Prior studies have yielded a large amount of evidence on the business view of "doing good is good for business". Firm CSR performance is directly linked with a firm's financial attributes, like, for example, CSR improves firm performance (Statman and Glushkov 2009; Wu and Shen 2013), mitigates firm risk (Jo and Na 2012; Lee and Faff 2009), reduces the cost of capital (El Ghoul et al. 2011; Sharfman and Fernando 2008), and increases the credit rating (Attig et al. 2013; Jiraporn et al. 2014). The literature mentioned above shows that CSR plays a vital role to improve the financial 
soundness of the firm and portray a better image of the company in front of assets' managers, investors, and consumers.

Typically, the corporate finance literature shows that socially responsible firms have better access to finance (Cheng et al. 2014) and low risk of default (Sun and Cui 2014; Boubaker et al. 2020). Prior studies stress that a firm with better CSR policies attracts both equity (El Ghoul et al. 2011) and debt (Goss and Roberts 2011) financing. On the debt side, long-term debt is considered a significant tool for debt financing. Thus, research shows that positive CSR performance reduces the cost of a bank loan. Usually, the firm also uses trade credit (Accounts Payable) to extend its financing along with debt. Trade credit is a vital source of funding for a firm with low cost, avoiding lengthy procedures, and maintaining sufficient liquidity. Outside investors also use trade credit as a source of information (Aktas et al. 2012; Boubaker et al. 2017).

Past research highlights that not only account payables but also the account receivables side matters, and that firms use trade credit channels to manage growth (Ferrando and Mulier 2013). Usually, firms promote a sale on credit to increase their revenues and offer a working capital opportunity to small or financially distressed firms (McMillan and Woodruff 1999). Firm trust in its buyer is a critical element that urges the firm to extend the trade credit facility (Wu et al. 2014). Indeed, a better relationship between a buyer and supplier builds mutual trust. Interestingly, some recent studies found that socially responsible firms ensure better contact with their stakeholders (Cheng et al. 2014; Deng et al. 2013).

The evidence mentioned above shows that firms with effective CSR policies have better access to finance and better relationship with stakeholders. The firm also uses a supplier side of trade credit to extend its liquidity. In contrast, firms also promote mutual trust with their stakeholders (shareholders, community, buyers, etc.). Following the corporate finance literature, we are unaware of any study that empirically investigates the impact of CSR on trade credit (both buyer and supplier sides). In this paper, we try to fill his gap.

Traditionally, firms give trade credit during the stable market condition. During the global financial crisis (2008-2009), the volume of trade credit reduces and businesses demand bank guarantees at this time (Tsuruta 2015). With a sample of developing countries (Argentina, Brazil, and Turkey), Bastos and Pindado (2013) found that crisis affects trade credit, and firms hold the trade credit for an extended period or delay payment to the supplier. While a firm's better CSR policies improve financial performance, during the crisis, this association does not exist (Wu and Shen 2013). Categorically, the second objective of this study is to check the consistency of the relationship between CSR and trade credit during the crisis.

In this paper, we use a sample of 6122 firm-year observations from the US manufacturing industry over the 2005-2012 period and control for firm characteristics as well as industry and year effects. We find that CSR-oriented businesses receive more trade credit from their supplier (account payables) and extend more trade credit to their buyers (account receivables). We further investigate this association during the crisis. Our findings show that CSR has a negative relationship with trade credit during the crisis. In other words, during the crisis, spending on CSR activities creates a negative impact on our supplier, and firms extend less trade credit to their buyer. Our results hold with alternate proxies of CSR and trade credit, an alternative sample selection criteria and time period, and control for potential endogeneity issues. We use the two-stage least squares (2SLS) method to address the endogeneity concern related to CSR. Following Jiraporn et al. (2014), we use average CSR scores of close geography firms (3-digit ZIP) and average CSR scores of industry peers (Fama-French 49 industry) as instruments in the first stage. We use a difference-in-difference (DID) regression estimation to check the difference in this association before and after the crisis of 2008-2009. Here, we find that improved CSR performance is beneficial to get more trade credit after the crisis.

In an additional test, we further investigate whether this relationship exists for both domestic and multinational corporations (MNCs). We find that CSR shows a positive association with trade credit for both domestic and multinationals firms. The crisis dummy shows a negative relationship with 
trade credit only for domestic firms. During the financial crisis, CSR shows a negative relationship with both the buyer and supplier sides of trade credit, but coefficients of the domestic sample are almost double in comparison to MNCs, because domestic firms cannot diversify their systematic risk and MNCs diversify their systematic risk through business expansion in less affected countries.

This paper contributes to the existing body of corporate finance literature in several ways. First, this study extends the research on how CSR increases the availability of finance (Attig et al. 2013; Cheng et al. 2014; El Ghoul et al. 2011; Goss and Roberts 2011; Sun and Cui 2014) and promotes a better relationship with stakeholders (Cheng et al. 2014, Wu and Shen 2013). Prior research mainly focusses on how CSR-oriented firms attract equity and long-term debt financing sources. Here, we use the supplier side of trade credit as a measure of financing. In contrast, our findings are also in support of past studies that show the importance of CSR to create better relationships with stakeholders. Second, we also add to the trade credit literature (Aktas et al. 2012; Albuquerque et al. 2015; El Ghoul et al. 2011) by showing CSR's association with it. Finally, we contribute to the literature of crisis (Lin and Chou 2015) and its effect on the trade credit behavior of firms (Bliss et al. 2015).

This empirical evidence offers some policy implications for financial management. First, firms can improve their overall trade credit through better CSR performance. Second, firms can reduce their investment in CSR activities during crisis or increase their foreign sales to improve trade credit during crisis. Lastly, this evidence supports the management decision to invest in socially responsible activities. The remainder of the paper is organized as follows. Section 2 reviews the existing literature on corporate social responsibility, trade credit, and financial crisis and hypothesis development. Section 3 presents a sample, variables, and descriptive statistics. Section 4 discusses the main results with robustness tests. Section 5 shows additional analysis results. Section 6 concludes the discussion of our findings.

\section{Literature Review}

In this section, we discuss the literature on corporate social responsibility and trade credit. Following this literature, we develop several hypotheses based on theories of trade credit linked with CSR. We aim to test these motives and to explain how CSR impacts the firm trade credit decisions.

\subsection{Why Is CSR Essential for the Firm?}

The corporate finance literature shows that if CSR expenditures spent on Nobel causes like the betterment of society or environment, then it will increase the firm value because "Doing Good is Good for Business" (Adhikari 2016; Elfenbein et al. 2012; Servaes and Tamayo 2013). Furthermore, two meta-analyses on the association between CSR and firm performance are also aligned with this notion. In their first study, Margolis and Walsh (2003) review the literature on CSR and firm performance from the last thirty years, from 1972 to 2002 . They thoroughly examine the 127 studies and report that 54 studies show a positive association between CSR and performance. The second time, they investigate 214 studies and state that, overall, CSR has a positive association with firm performance, which is smaller in recent decades (Margolis et al. 2009).

From a broad perspective, investors want to earn a maximum profit on a given level of firm risk. A firms' social performance also reduces the probability of financial risk along with improved firm financial performance (Herremans et al. 1993). ${ }^{1}$ A recent study shows that improved CSR has a positive impact on firm value because CSR performance reduces excessive risk-taking and risk avoidance (Harjoto and Laksmana 2016). ${ }^{2}$ In the same manner, Cai et al. (2015) find that corporate environmental

$1 \quad$ Herremans et al. (1993) conducted this study with the help of large US manufacturing firms from 1982-1987. They showed that better CSR performance provides investors better stock returns and lower risk.

2 Harjoto and Laksmana (2016) conducted this study on 1718 US firms during 1998 to 2011. They used MSCI ESG data as a measure of CSR, Tobin's Q for performance and risk taking is a combination of five different variables (CAPEX, RDEX, ACQEX, STDROA and STDRET). 
responsibility engagement inversely relates to firm risk after controlling for different risk determinants. CSR engagement also plays an important role in reducing idiosyncratic risk (Lee and Faff 2009) and stock price crash risk (Kim et al. 2014), forgoing evidence stress about the risk-mitigating view of CSR.

Prior studies have documented several pieces of evidence on CSR association with the cost of capital (Goss and Roberts 2011; Kempf and Osthoff 2007; Sharfman and Fernando 2008). Using a large sample of US firms, El Ghoul et al. (2011) find that firms with better CSR performance exhibit cheaper equity financing. Moreover, an increase in CSR performance improves the firm credit rating; it means that more affordable capital is available (Attig et al. 2013; Jiraporn et al. 2014). Consequently, the mentioned studies show that firms with better CSR performance reduce the firm cost of equity and cost of capital, and improve its creditworthiness.

Following the noted evidence, we conclude that CSR has a significant association with several firm financial attributes (firm performance, risk, idiosyncratic risk, stock price crash risk, cost of capital, cost of equity, credit rating, etc.). However, the relationship between CSR and trade credit is still a question in business research. In this paper, we try to investigate the impact of CSR on the supply and demand sides of trade credit.

\subsection{Hypothesis}

\subsubsection{CSR and Trade Credit}

Trade credit is a financial instrument for a business offered by a supplier to its customer. $\mathrm{Ng}$ et al. (1999) indicate that, usually, trade credit is provided to the buyer from a supplier whenever they offer terms that allow a delayed payment. Trade credit supply (i.e., account receivables) is mainly meant to promote firm sales by providing working capital financing to other small or financially distressed firms (McMillan and Woodruff 1999). Both suppliers and customers use trade credit to reduce transaction costs. This means that the firm uses a more significant amount of trade credit when its transactions are more frequent. Ferris (1981) states that if the buyers pay bills after every delivery, they must have sufficient liquidity. Furthermore, firms extend trade credit to increase sales and reduce the inventory maintains (finish goods) cost when they face an uncertain demand for their product (Bougheas et al. 2009). Therefore, firms use trade credit for both transaction and financial motives.

For the last two decades, academic researchers have shown the link between bank credit and trade credit. Demirguc-Kunt and Maksimovic (2001) used firm-level data from 39 countries and found that country banking system development, and legal infrastructure play an essential role in the use of trade credit (both receivables and payables). ${ }^{3}$ A recent study on quarterly data of 1213 Chinese firms shows that bank loan has a significant impact on both the supply (i.e., receivables) and demand (i.e., payables) of trade credit (Lin and Chou 2015). ${ }^{4}$ Another study conducted on 80,625 small and medium enterprises shows that the better availability of bank loans improves the trade credit (both payables and receivables) (Tsuruta 2015). Besides this, they highlight that the association between bank loans and trade payables is complimentary in small enterprises.

Several recent articles, including Attig et al. (2013), Boubaker et al. (2019), Jiraporn et al. (2014), and (Sun and Cui 2014) suggest that CSR-oriented businesses have better access to finance due to an improved credit rating. Likewise, Goss and Roberts (2011) show that positive CSR performance is instrumental in getting a bank loan at cheaper rates. This means that better CSR performance increases the firm creditworthiness in front of the lender and is helpful to get a loan at a lower rate. Based on this evidence, we hypothesize that CSR and trade credit (account payables) exhibit a positive relationship through the bank lending channel.

3 Moreover, they found that firms use more bank credit than trade credit in countries with an effective legal system. They also suggest that trade credit is complementary for business in the development of financial intermediaries.

4 With the financial crisis of 2008-2009, they found that bank loan has a positive relationship with receivables and a negative relationship with the payables side of trade credit. 
Hypothesis 1 (H1). Firms with better CSR performance obtains more trade credit from their supplier.

Trust is an essential element for trade credit provision to the buyer. The credit provider only considers the creditworthiness of the buyer ${ }^{5}$ in trade credit activity. Wu et al. (2014) explore the impact of trust on trade credit provision. They find that private firms located in highly trusted regions extend more credit to the buyer and use more credit from the supplier. Trust is also very helpful to reduce the collection of receivables and payment of payables' time. Some studies stress that often trade-credit is used as a proxy for interfirm trust and reputation (Fafchamps 1997; Fisman and Raturi 2004). In other words, if the firm has trust in its buyer, then their receivables increase, and if its supplier trusts the firm, then their payables increase.

The literature linking CSR and trust is nascent. Cheng et al. (2014) showed that a firm faces significantly lower capital constraints with better CSR performance. Here, they also mention that CSR-oriented policies show firm engagement and commitment to stakeholders based on cooperation and trust. Therefore, CSR plays an important role in promoting mutual trust between stakeholders (like buyer and supplier). A stream of the article also concludes that CSR is handy for creating a better relationship with stakeholders and promoting the value maximization goal (Becchetti et al. 2012; Choi and Wang 2009; Deng et al. 2013). Thus, better corporate social performance increases the demand for trade credit through trust and stakeholder value maximization channels. This notion leads to the following hypothesis:

Hypothesis 2 (H2). Firms with better CSR performance extends more trade credit to their buyer.

\subsubsection{CSR and Trade Credit during the Crisis}

Following the bankruptcy of Lehman Brothers in 2007-2008, the profitability of US businesses rapidly deteriorated. This financial crisis begins due to the subprime mortgage crisis in the US market in 2007 and after that oil prices quickly rises in 2008. Previous researchers reported that total payout had inverse effects during the financial crisis of 2008-2009 (Bliss et al. 2015). Tsuruta (2015) found that overall trade credit volume reduced during the financial crisis, but when a company has a bank guarantee, then it increases the trade credit from its supplier. Therefore, the financial crisis of 2008-2009 effected the trust level of the trade credit supplier to their customer and, during the crisis, they needed bank guarantee as collateral. Love et al. (2007) indicate that trade credit ${ }^{6}$ lost or inverted its association during and after the Asian crisis of 1997.

Historical evidence stresses that CSR performance mostly affects firm performance positively. However, the literature also provides evidence that crisis affects the relationship between CSR and firm performance. Lins et al. (2017) found that CSR has a positive relationship with abnormal returns during the crisis, but after the crisis, this relationship does not exist. In another study, Wu and Shen (2013) showed that CSR has a significant positive association with ROA and non-interest income, but during the crisis, this relationship lost its significance. Following the mentioned studies, we argue that if CSR's association with firm financial attributes' changes during the crisis, this means that means crisis also affects the CSR relationship with trade credit. This concept leads to the following hypotheses:

Hypothesis 3 (H3). Financial crisis affects the association between CSR and the supply side of trade credit.

Hypothesis 4 (H4). Financial crisis affects the association between CSR and the demand side of trade credit.

5 Normally, trade credit activity is completed without providing any collateral.

6 They use trade receivables, trade payables and net trade credit as dependent variables. 


\section{Research Design}

In this section, we define our sample and variables construction, the main model, and sample descriptive analysis.

\subsection{Sample}

Our sample consists of US firms from Datastream, Worldscope, and MSCI ESG databases. Following the previous literature on trade credit, we only include the manufacturing firms (SIC 2000-5999) and exclude non-manufacturing firms due to their different trade credit behavior (El Ghoul and Zheng 2016; Tsuruta 2015). We include firms with data on MSCI ESG rating and all the variables in our baseline model and delete observations with missing data. We also exclude data before 2005 due to considerable changes in previous years (like Russel 100 and Russel 3000 included in their coverage in 2001 and 2003, respectively). The second objective of taking data from 2005 to 2012 is to create a symmetrical data window around the 2008-2009 crisis. Our data consist of 1294 manufacturing firms from 2005 to 2012, with a total number of 6211 firm-year observations.

\subsection{Variables}

Due to the non-availability of the total volume of trade credit, we followed prior studies and used accounts' receivables and payables to measure the receipt and offers of trade credit (El Ghoul and Zheng 2016; Wu et al. 2014). We used total account receivables/total sales (AR) and total account payables/total sales $(A P)$ to measure the use and offering of trade credit respectively. Further, we scaled both measures of trade credit by total sales to increase the comparability of our results (El Ghoul and Zheng 2016).

We used MSCI ESG (previously known as KLD) data as a measure of CSR. MSCI ESG evaluates a firm's social performance in seven main qualitative dimensions (community, corporate governance, diversity, employee relations, environment, human rights, and product quality/safety). Furthermore, each dimension of CSR evaluates different strengths and concerns. Each strength and concern consist of binary response (' 1 ' for the presence and ' 0 ' for the absence of that strength or concern). For more detailed CSR dimensions (qualitative issue areas) strengths and concerns, see "Annexure A \& B". To rate these dimensions, MSCI ESG uses media reports, surveys, financial statements, government reports, legal journals, and proxy statements (Attig et al. 2013). Following the historical literature, we also excluded the corporate governance dimension from our final calculation of CSR measure due to its distinct characteristics (Boubaker and Nguyen 2012, 2014; El Ghoul et al. 2011).

With the remaining six dimensions, we calculated a firm's CSR score in each year by total strengths minus total concerns, as follows:

$$
\mathrm{CSR}_{i, t}=\sum \text { CSR_strengths } s_{i, t}-\sum \text { CSR_concerns } i_{i, t}
$$

We used data from 2005 to 2012, and the financial crisis 2008-2009 separates this period. The supply and consumption of trade credit changed a lot during the financial crisis. Tsuruta (2015) concluded that, during the financial crisis of 2008-2009, firms only give trade credit to those firms with a bank guarantee. We created a dummy variable for the financial crisis and used 2008-2009 as a period of crisis (Lin and Chou 2015; Vazquez and Federico 2015). To check the impact of CSR on trade credit during the crisis, we used an interaction term of financial crisis and CSR.

In line with the previous literature on trade credit, we used some control variables that may affect the trade credit (El Ghoul and Zheng 2016; Mateut et al. 2015; Tsuruta 2015). First, we used the ratio of net income divided by total assets to control for the profitability $(R O A)$ of the firm. Second, we included the natural logarithm of total sales in USD millions to control the firm size (SIZE). Third, we used the ratio of long-term debt to total assets to control for firm liquidity (Debt/assets). Fourth, we included the ratio of total property plant and equipment scaled by total assets (Fixed asset/assets). Fifth, we used the years of experience in year $\mathrm{t}(\mathrm{Age})$. Sixth, we included the percentage change in the total sales 
from the year $\mathrm{t}-1$ to $\mathrm{t}$ to control the sales growth (Sales growth). Finally, we used the ratio of total sales scaled by total assets to control the revenue generation capacity (Sales/assets) and the ratio of cost of goods sold to total assets to control production capacity (CGS/assets) of firms. Further, to control the year and industry effects, we used dummy variables for each year and each Fama French 49 industry. Appendix A contains the definitions and data sources of all the variables used in our baseline model.

\subsection{Main Model}

To check the impact of CSR on trade credit, we used the two different measures of trade credit $\mathrm{AR}$ (=accounts receivables/sales) and AP (=accounts payables/sales). Using the variables mentioned above, we estimate the following equations

$$
\begin{gathered}
\mathrm{TC}_{i, t}=\alpha_{i, t}+\beta_{1} \mathrm{CSR}_{i, t}+\beta_{2} \text { Control }_{i, t}+\varepsilon_{i, t} \\
\mathrm{TC}_{i, t}=\alpha_{i, t}+\beta_{1} \mathrm{CSR}_{i, t}+\beta_{2} \text { Crisis }_{t}+\beta_{3} \mathrm{CSR}_{i, t} \times \text { Crisis }_{t}+\beta_{4} \text { Control }_{i, t}+\varepsilon_{i, t}
\end{gathered}
$$

where $T C$ is the trade credit measures (AR and AP). CSR gauges firm social performance. The crisis is a dummy variable ( 1 for the year 2008 and 2009). CSR $\times$ Crisis is an interaction term of CSR and crisis to check the impact of CSR on trade credit during the crisis. Control is the list of firm-level determinants of trade credit (ROA, Long-term debt/assets, Fixed asset/assets, Firm age, Sales growth, Sales/assets, CGS/assets, Year, and Industry dummies).

\subsection{Sample Descriptive Analysis}

Table 1 summarizes the sample structure of our key-dependent and independent variables. This sample only includes the US manufacturing sector. Panel ' $\mathrm{A}$ ' depicts the year-wise distribution and mean values ( $A R, A P$, and CSR). Both forms of trade credit (buyers and suppliers) show a lower mean value during the crisis period (2008-2009) than before and after the crisis. After the crisis (2010-2012), the US manufacturing sector extended more credit on sales to increase their business activity (two percent increase in the value of trade credit after the crisis). The mean value of CSR across the years is close to zero, but after the financial crisis (2008-2009), CSR mean is significantly positive in our sample.

Table 2 presents the summary statistics of all variables. Two main dependent variables $A R$ and $A P$ are shown to compare their means, standard deviations, minimum, median, and maximum (winsorized at $5 \%$ level). The mean value of $A R(18.4 \%)$ is larger than $A P(11.9 \%)$, which indicates that manufacturing firms in the US extend more trade credit to their buyer rather than a supplier. The mean CSR score of this sample is -0.246 and 5 th percentile and 95th percentile values are -6 and 8 respectively.

Our sample comprises large firms (Size $=13.3$; $\$ 567$ million), with high return on assets ratio $(R O A=4 \%)$, high sales growth (Sales growth $=11.1 \%)$ and mature firms (Age $=21$ years). In our sample, firms have $18.3 \%$ debt to assets and $27.9 \%$ fixed assets to assets ratio. Manufacturing firms in the US normally perform well and, their sales double to the value and cost of their assets of goods sold (COGS) is $69 \%$ of total sales. Control variables are winsorized at a five percent level to remove the influence of outliers from our final results.

Table 3 reports the correlation matrix among the independent variables. CSR has a negative correlation with Debt/assets, Fixed assets/assets. Sales growth, Sales/assets, and CGS/sales. ROA, Size, and Age have significant positive correlations with CSR. We also computed the variance inflation factor (VIF) for all independent variables, to confirm the absence of multicollinearity. In the VIF results, the most significant value of VIF observed in our full model is 2.58 (fixed assets/assets) and the VIF of all other variables is below 2. A common rule of thumb is that VIF is more than 10.0, pointing out multicollinearity problems (Liu and Ritter 2011). Collectively, we can say that multicollinearity is not a problem in our data. 
Table 1. Sample structure of dependent and independent variables by year and industry.

\begin{tabular}{|c|c|c|c|c|}
\hline \multicolumn{5}{|l|}{ Panel A: Sample structure by year } \\
\hline Year & Obs & AR & AP & CSR \\
\hline 2005 & 728 & 0.177 & 0.114 & -0.438 \\
\hline 2006 & 748 & 0.173 & 0.113 & -0.500 \\
\hline 2007 & 750 & 0.190 & 0.125 & -0.452 \\
\hline 2008 & 806 & 0.174 & 0.114 & -0.400 \\
\hline 2009 & 782 & 0.164 & 0.105 & -0.425 \\
\hline 2010 & 822 & 0.184 & 0.118 & -0.252 \\
\hline 2011 & 788 & 0.206 & 0.131 & 0.033 \\
\hline 2012 & 787 & 0.206 & 0.130 & 0.432 \\
\hline Total & 6211 & 0.184 & 0.119 & -0.250 \\
\hline \multicolumn{5}{|c|}{ Panel B: Sample structure by industry } \\
\hline Industry & Obs & AR & AP & CSR \\
\hline Automobiles and Trucks & 164 & 0.213 & 0.132 & -0.963 \\
\hline Restaurants, Hotels, Motels & 149 & 0.111 & 0.106 & -0.396 \\
\hline Electronic Equipment & 705 & 0.162 & 0.089 & 0.152 \\
\hline Retail & 518 & 0.148 & 0.200 & -0.079 \\
\hline Communication & 257 & 0.166 & 0.110 & -0.265 \\
\hline Steel Works Etc. & 141 & 0.180 & 0.096 & -0.929 \\
\hline Utilities & 520 & 0.181 & 0.120 & -0.517 \\
\hline Machinery & 405 & 0.189 & 0.092 & -0.422 \\
\hline Chemicals & 292 & 0.273 & 0.164 & -1.134 \\
\hline Tobacco Products & 35 & 0.264 & 0.159 & -1.429 \\
\hline Wholesale & 284 & 0.223 & 0.150 & -0.232 \\
\hline Construction Materials & 198 & 0.152 & 0.076 & -0.480 \\
\hline Pharmaceutical Products & 328 & 0.176 & 0.084 & -0.137 \\
\hline Electrical Equipment & 112 & 0.185 & 0.106 & -0.732 \\
\hline Consumer Goods & 140 & 0.109 & 0.066 & 1.257 \\
\hline Petroleum and Natural Gas & 94 & 0.419 & 0.363 & -2.596 \\
\hline Medical Equipment & 356 & 0.167 & 0.056 & -0.371 \\
\hline Measuring and Control Equipment & 192 & 0.142 & 0.064 & 0.083 \\
\hline Apparel & 86 & 0.156 & 0.096 & 0.081 \\
\hline Almost Nothing & 55 & 0.085 & 0.028 & -0.473 \\
\hline Shipping Containers & 46 & 0.378 & 0.280 & -0.630 \\
\hline Business Services & 32 & 0.145 & 0.082 & -0.750 \\
\hline Transportation & 283 & 0.199 & 0.131 & -0.516 \\
\hline Food Products & 156 & 0.119 & 0.089 & 0.455 \\
\hline Printing and Publishing & 89 & 0.182 & 0.074 & 0.955 \\
\hline Candy $\mathcal{E}$ Soda & 71 & 0.272 & 0.180 & 0.211 \\
\hline Computer Hardware & 135 & 0.363 & 0.238 & 1.289 \\
\hline Aircraft & 55 & 0.218 & 0.144 & -0.527 \\
\hline Defense & 25 & 0.067 & 0.024 & -0.480 \\
\hline Recreation & 66 & 0.203 & 0.095 & 0.136 \\
\hline Textiles & 19 & 0.140 & 0.079 & 0.474 \\
\hline Business Supplies & 106 & 0.199 & 0.125 & 0.670 \\
\hline Shipbuilding, Railroad Equipment & 31 & 0.096 & 0.086 & -1.742 \\
\hline Rubber and Plastic Products & 51 & 0.087 & 0.059 & -0.510 \\
\hline Beer \& Liquor & 15 & 0.270 & 0.148 & 1.400 \\
\hline Total & 6211 & 0.189 & 0.124 & -0.558 \\
\hline
\end{tabular}

This table gives the year and industry composition of the sample. The period covered is 2005 to 2012 . Firms are grouped into the industry based on Fama-French 49 industry classification. The primary sample consists of 6211 firm-year observations from the US manufacturing sector over the 2005-2012 period. AR is the ratio of total receivables to total sales; $A P$ is the ratio of total payables to total sales; CSR is calculated as total strengths minus total concerns. Definitions and data sources of all variables are provided in Appendix A. In Table 1 Panel 'B,' we report the sample structure by industry using the Fama-French 49 industrial classification. Our sample mostly consists of Electronic Equipment, Utilities, and Retail industries. Our sample depicts that Petroleum and Natural Gas industry extend more trade credit (AR 41.9\%, AP 36.3\%) and have the worst CSR mean due to a significant contribution to environmental pollution. The Medical Equipment industry increases its business activity by extending more credit to their supplier. Following the social behavior of the manufacturing sector, the Computer Hardware and Beer \& Liquor industries have the best social practices. 
Table 2. Summary statistics.

\begin{tabular}{|c|c|c|c|c|c|c|c|c|}
\hline Variables & Obs & Mean & STD & 5th Percentile & 25th Percentile & Median & 75th Percentile & 95th Percentile \\
\hline \multicolumn{9}{|c|}{ Dependent variables } \\
\hline$A R$ & 6211 & 0.184 & 0.386 & 0.000 & 0.005 & 0.024 & 0.129 & 1.530 \\
\hline$A P$ & 6211 & 0.119 & 0.253 & 0.000 & 0.003 & 0.014 & 0.078 & 0.995 \\
\hline \multicolumn{9}{|c|}{ Variable of interest } \\
\hline $\operatorname{CSR}$ & 6211 & -0.246 & 2.315 & -6.000 & -2.000 & -1.000 & 1.000 & 8.000 \\
\hline \multicolumn{9}{|l|}{ Control variables } \\
\hline$R O A$ & 6211 & 0.040 & 0.079 & -0.172 & 0.015 & 0.048 & 0.088 & 0.167 \\
\hline Size & 6211 & 13.248 & 1.844 & 9.964 & 11.855 & 13.257 & 14.572 & 16.596 \\
\hline Debt/assets & 6211 & 0.183 & 0.160 & 0.000 & 0.012 & 0.167 & 0.298 & 0.522 \\
\hline Fixed assets/assets & 6211 & 0.279 & 0.213 & 0.036 & 0.107 & 0.212 & 0.419 & 0.740 \\
\hline Age & 6211 & 21.169 & 12.776 & 2.000 & 10.000 & 20.000 & 34.000 & 39.000 \\
\hline Sales growth & 6211 & 9.362 & 17.751 & -21.346 & -0.874 & 7.477 & 17.360 & 53.207 \\
\hline Sales/assets & 6211 & 2.357 & 4.541 & 0.007 & 0.083 & 0.396 & 5.932 & 17.849 \\
\hline CGS/sales & 6211 & 0.688 & 0.529 & 0.085 & 0.272 & 0.541 & 0.949 & 2.009 \\
\hline
\end{tabular}

This table presents the number of observations, mean, standard deviation, 5th percentile, 25th percentile, median, 75th percentile, and 95th percentile for this paper used variables. AR is the ratio of total receivables to total sales; $A P$ is the ratio of total payables to total sales; $C S R$ is calculated as total strengths minus total concerns; $R O A$ is the ratio of net income divided by total assets; Size is the natural logarithm of total sales in USD millions; Debt/assets is the ratio of long-term debt to total assets; Fixed asset/assets is the total of property plant and equipment scaled by total assets; Age is the years of experience in year $\mathrm{t}$; Sales growth is the percentage change in the total sales from the year $\mathrm{t}-1$ to $\mathrm{t}$; Sales/assets is the ratio of total sales scaled by total assets; CGS/assets is the ratio of cost of goods sold to total assets. The main sample consists of 6211 firm-year observations from the US manufacturing sector over the 2005-2012 period. Definitions and data sources of all variables are provided in Appendix A. 
Table 3. Correlation.

\begin{tabular}{|c|c|c|c|c|c|c|c|c|c|c|c|}
\hline Variables & & (1) & (2) & (3) & (4) & (5) & (6) & (7) & (8) & (9) & VIF \\
\hline (1) & CSR & 1.0000 & & & & & & & & & 1.52 \\
\hline (2) & $R O A$ & 0.1088 * & 1.0000 & & & & & & & & 1.25 \\
\hline (3) & Size & 0.0590 * & 0.0675 * & 1.0000 & & & & & & & 1.93 \\
\hline (4) & Debt/assets & -0.0261 & -0.1514 * & 0.0710 * & 1.0000 & & & & & & 1.41 \\
\hline (5) & Fixed assets/assets & -0.0745 * & 0.0010 & $0.0855 *$ & 0.3244 * & 1.0000 & & & & & 2.58 \\
\hline (6) & Age & $0.1537^{*}$ & 0.1735 * & 0.3604 * & 0.0584 * & 0.1679 * & 1.0000 & & & & 1.46 \\
\hline (7) & Sales growth & -0.0630 * & 0.1567 * & -0.0744 * & -0.0900 * & -0.1183 * & -0.1788 * & 1.0000 & & & 1.27 \\
\hline (8) & Sales/assets & $-0.0812 *$ & -0.0726 * & 0.5294 * & -0.1705 * & -0.1292 * & -0.0261 & 0.0275 & 1.0000 & & 1.75 \\
\hline (9) & CGS/sales & $-0.0999 *$ & 0.1433 * & -0.0250 & -0.1394 * & -0.0031 & -0.0003 & 0.0086 & -0.0246 & 1.0000 & 1.99 \\
\hline
\end{tabular}

This table reports the correlation coefficients and variance inflation factors (VIF) of independent and control variables. CSR is calculated as total strengths minus total concerns; $R O A$ is the ratio of net income divided by total assets; Size is the natural logarithm of total sales in \$US millions; Debt/assets is the ratio of long-term debt to total assets; Fixed asset/assets is the total of property plant and equipment scaled by total assets, Age is the years of experience in year $t$, Sales growth is the percentage change in the total sales from the year $t-1$ to $t$; Sales/assets is the sector over the 2005-2012 period. Definitions and data sources of all variables are provided in Appendix A. * indicates significance at the $1 \%$ level. 


\section{Main Evidence}

To empirically investigate the relationship between corporate social responsibility and trade credit, we use pooled ordinary least square (OLS) regressions estimation with standard errors adjusted for clustering by firm-level (Attig et al. 2013; Wu et al. 2017). This regression estimation technique is very famous in the corporate finance literature. Mainly, we use Stata13 for all econometric analysis.

\subsection{The Relationship between CSR, Financial Crisis and Trade Credit}

Table 4 presents our main results estimated for Equations (2) and (3). ${ }^{7}$ Our baseline models, Models (1) and (3), present estimates of regressing AR and AP on the CSR and firm-level control variables. Our main results show a positive relationship between trade credit (AR and AP) and corporate social performance. In Model (1), CSR shows a significant positive impact on the buyer side of trade credit (AR). These findings are consistent with the Cheng et al. (2014), suggesting that CSR promotes trust, and Wu et al. (2014), suggesting that trust increases the firm sales on trade credit. This finding states that the socially responsible organization has trust in their buyers, so that a firm with high social performance lends more trade credit to their buyers $(H 2)$.

In Model (3) of Table 4, we estimate the Equation (2) using the AP as a dependent variable. The finding shows that CSR performance has a significant positive association with the supplier side of trade credit. This result is consistent with prior literature, where better CSR performance shows creditworthiness of firms with banks (Goss and Roberts 2011) and a good bank loan history increases the supply of trade credit (Lin and Chou 2015). This finding underlines that firms with socially responsible behavior can get more trade credit from their supplier (H1). These results are also consistent with Zhang et al. (2014). ${ }^{8}$

To test our next two hypotheses, we add a crisis dummy and an interaction term of CSR and crisis. In Models (3) and (4), we estimate Equation (3) by using AR and AP as a measure of trade credit. In both models, the crisis dummy shows a negative relationship with trade credit, but CSR still has a significant positive association with trade credit (buyer and supplier). Consistent with the previous literature, Tsuruta (2015) states that overall trade credit volume reduces during the crisis and Bliss et al. (2015) find that the overall payout policy had inverse effects during the financial crisis 2008-2009. In these models, we have an objective to check whether a positive relationship between CSR and trade credit also exists, when an organization faces a lack of trust during a financial crisis. The interaction term of CSR and crisis has a significant negative association with both demand and supply of trade credit. There is convincing evidence in the literature that CSR relationship with firm financial attributes losses its significance or behaves inversely during crisis (Lins et al. 2017; Wu and Shen 2013). These results show that socially responsible firms reduced trade credit (buyer and supplier) during the financial crisis (H3 and H4).

Table 4 presents the results of CSR impact on trade credit along with several firm-level controls. return on assets (ROA) has a significant positive relationship with trade credit; it means that firms with high profitability tend to offer more trade credit (Bougheas et al. 2009; Tsuruta 2015). The coefficient of Size $(\ln ($ sales $))$ is statistically significant at $1 \%$, showing that larger firms have less trade credit (El Ghoul and Zheng 2016; Lin and Chou 2015). Debt/assets show a positive association with trade credit significant at a 1\% level, consistent with Mateut et al. (2015). Fixed assets/assets have a negative impact only on the buyer side of trade credit (El Ghoul and Zheng 2016; Giannetti et al. 2011). Age shows a positive relationship with trade credit significant at $1 \%$. Sales growth has a significant negative association with trade credit, showing that a firm with higher sales growth has less trade credit (buyer and supplier) (El Ghoul and Zheng 2016). Following (Lin and Chou 2015), we also add separate

\footnotetext{
Tables 4-10 stars indicate that "****, and *** show $p$-value less than $10 \%, 5 \%$, and $1 \%$ levels, respectively".

In this paper, authors find a positive relationship between charitable donations and the supply side of trade credit. They use the Chinese firm's data from 2003 to 2010.
} 
firm-level determinants; Sales/assets for $A R$ and CGS/sales for AP. Our results interpret that, with a high Sales/assets ratio, a firm tends to have more trade credit for their buyer and with high CGS/sales, a firm gets more trade credit from their supplier. Further, adjusted R-square in Models (1-4) are similar to the prior literature (El Ghoul and Zheng 2016; Zhang et al. 2014).

Table 4. Corporate social responsibility, financial crisis, and trade credit.

\begin{tabular}{|c|c|c|c|c|}
\hline \multirow{2}{*}{ Variables } & \multicolumn{2}{|c|}{ AR } & \multicolumn{2}{|c|}{ AP } \\
\hline & (1) & (2) & (3) & (4) \\
\hline CSR & $\begin{array}{c}0.027^{* * *} \\
(6.01)\end{array}$ & $\begin{array}{c}0.031^{* * *} \\
(7.10)\end{array}$ & $\begin{array}{c}0.016^{* * *} \\
(5.22)\end{array}$ & $\begin{array}{c}0.020 * * * \\
(6.39)\end{array}$ \\
\hline Crisis & & $\begin{array}{c}-0.034^{* * * *} \\
(-2.67)\end{array}$ & & $\begin{array}{l}-0.020^{* *} \\
(-2.37)\end{array}$ \\
\hline CSR $\times$ Crisis & & $\begin{aligned}-0.019^{* * *} & (-4.54)\end{aligned}$ & & $\begin{array}{c}-0.014^{* * *} \\
(-5.01)\end{array}$ \\
\hline$R O A$ & $\begin{array}{c}0.551^{* * *} \\
(6.07)\end{array}$ & $\begin{array}{c}0.548^{* * *} \\
(6.08)\end{array}$ & $\begin{array}{c}0.217^{* * *} \\
(3.97)\end{array}$ & $\begin{array}{l}0.215^{* * *} \\
(3.95)\end{array}$ \\
\hline Size & $\begin{array}{l}-0.141^{* * *} \\
(-15.77)\end{array}$ & $\begin{array}{l}-0.141^{* * * *} \\
(-15.85)\end{array}$ & $\begin{array}{l}-0.073^{* * *} \\
(-16.21)\end{array}$ & $\begin{array}{c}-0.073^{* * *} \\
(-16.28)\end{array}$ \\
\hline Debt/assets & $\begin{array}{c}0.410^{* * * *} \\
(6.66)\end{array}$ & $\begin{array}{c}0.407^{* * *} \\
(6.65)\end{array}$ & $\begin{array}{l}0.193^{* * *} \\
(5.07)\end{array}$ & $\begin{array}{c}0.190 * * * \\
(5.02)\end{array}$ \\
\hline Fixed assets/assets & $\begin{array}{l}-0.169 * * * \\
(-3.01)\end{array}$ & $\begin{array}{c}-0.170^{* * *} \\
(-3.02)\end{array}$ & $\begin{array}{l}-0.005 \\
(-0.11)\end{array}$ & $\begin{array}{l}-0.005 \\
(-0.12)\end{array}$ \\
\hline Age & $\begin{array}{c}0.003 * * * \\
(3.97)\end{array}$ & $\begin{array}{c}0.003 * * * \\
(3.95)\end{array}$ & $\begin{array}{c}0.002^{* * *} \\
(3.08)\end{array}$ & $\begin{array}{c}0.002 * * * \\
(3.04)\end{array}$ \\
\hline Sales growth & $\begin{array}{l}-0.001 * * * \\
(-3.43)\end{array}$ & $\begin{array}{l}-0.001^{* * * *} \\
(-3.34)\end{array}$ & $\begin{array}{l}-0.000^{* *} \\
(-2.44)\end{array}$ & $\begin{array}{c}-0.000 * * \\
(-2.32)\end{array}$ \\
\hline Sales/assets & $\begin{array}{c}0.015^{* * *} \\
(8.15)\end{array}$ & $\begin{array}{c}0.015^{* * *} \\
(8.27)\end{array}$ & & \\
\hline CGS/sales & & & $\begin{array}{c}0.047^{* * *} \\
(2.60)\end{array}$ & $\begin{array}{c}0.047^{* * *} \\
(2.62)\end{array}$ \\
\hline Constant & $\begin{array}{l}1.704^{* * *} \\
(16.24)\end{array}$ & $\begin{array}{c}1.718^{* * *} \\
(16.34)\end{array}$ & $\begin{array}{l}0.802 * * * \\
(13.80)\end{array}$ & $\begin{array}{c}0.811^{* * *} \\
(13.94)\end{array}$ \\
\hline Obs & 6211 & 6211 & 6211 & 6211 \\
\hline $\begin{array}{l}\text { Year and Industry } \\
\text { FE }\end{array}$ & Yes & Yes & Yes & Yes \\
\hline Firm Cluster & Yes & Yes & Yes & Yes \\
\hline $\operatorname{Adj} R^{2}$ & 0.336 & 0.338 & 0.315 & 0.317 \\
\hline
\end{tabular}

This table report results from regressing trade credit on corporate social responsibility measure and firm controls. $A R$ is the ratio of total receivables to total sales; $A P$ is the ratio of total payables to total sales; CSR is calculated as total strengths minus total concerns; Crisis is a dummy variable that takes the value one for the year 2008 and 2009; ROA is the ratio of net income divided by total assets; Size is the natural logarithm of total sales in \$US millions; Debt/assets is the ratio of long-term debt to total assets; Fixed asset/assets is total of property plant and equipment scaled by total assets; Age is the years of experience in year $\mathrm{t}$; Sales growth is the percentage change in the total sales from the year $\mathrm{t}$ - 1 to $\mathrm{t}$; Sales/assets is the ratio of total sales scaled by total assets; CGS/assets is the ratio of cost of goods sold to total assets. The main sample consists of 6211 firm-year observations from the US manufacturing sector over the 2005-2012 period. Definitions and data sources of all variables are provided in Appendix A. Unreported industry controls are based on the Fama and French 49 industry classification. Robust $t$-statistics adjusted for clustering by the firm is reported inside the parentheses (Petersen 2009). * ${ }^{* *}$, and ${ }^{* * *}$ indicate two-tailed significance at the $10 \%$, $5 \%$, and $1 \%$ levels, respectively.

\subsection{Sensitivity Tests}

In this subsection, we test the sensitivity of our findings with alternative proxies of dependent and independent variables and an alternative sample, and overcome the endogeneity concerns.

\subsubsection{Alternate Proxies for CSR and Trade Credit}

We first tested the sensitivity of our results with alternate proxies for CSR and trade credit. We began with our primary independent variable of interest. In our main analysis, we used the 
most popular aggregation method for CSR (total strengths-total concerns). However, a drawback of this approach is a lack of comparability, due to changes in some strengths and concerns across dimensions and years. ${ }^{9}$ However, to overcome this issue, we used the aggregation method developed by Manescu (2011). Table 5 Models (1-4) present the results with CSR average measures. First, we calculate the average strength minus average concern for each dimension of CSR. Then we use these individual dimensions score to calculate average CSR. After using the alternate proxy, CSR still had a significant positive association with both the buyer and supplier side of trade credit, but, during the crisis, it showed an inverse association. All other firm-level determinants show the same relationship as the one in our main results.

Table 5. Alternate proxies for corporate social responsibility (CSR) and trade credit.

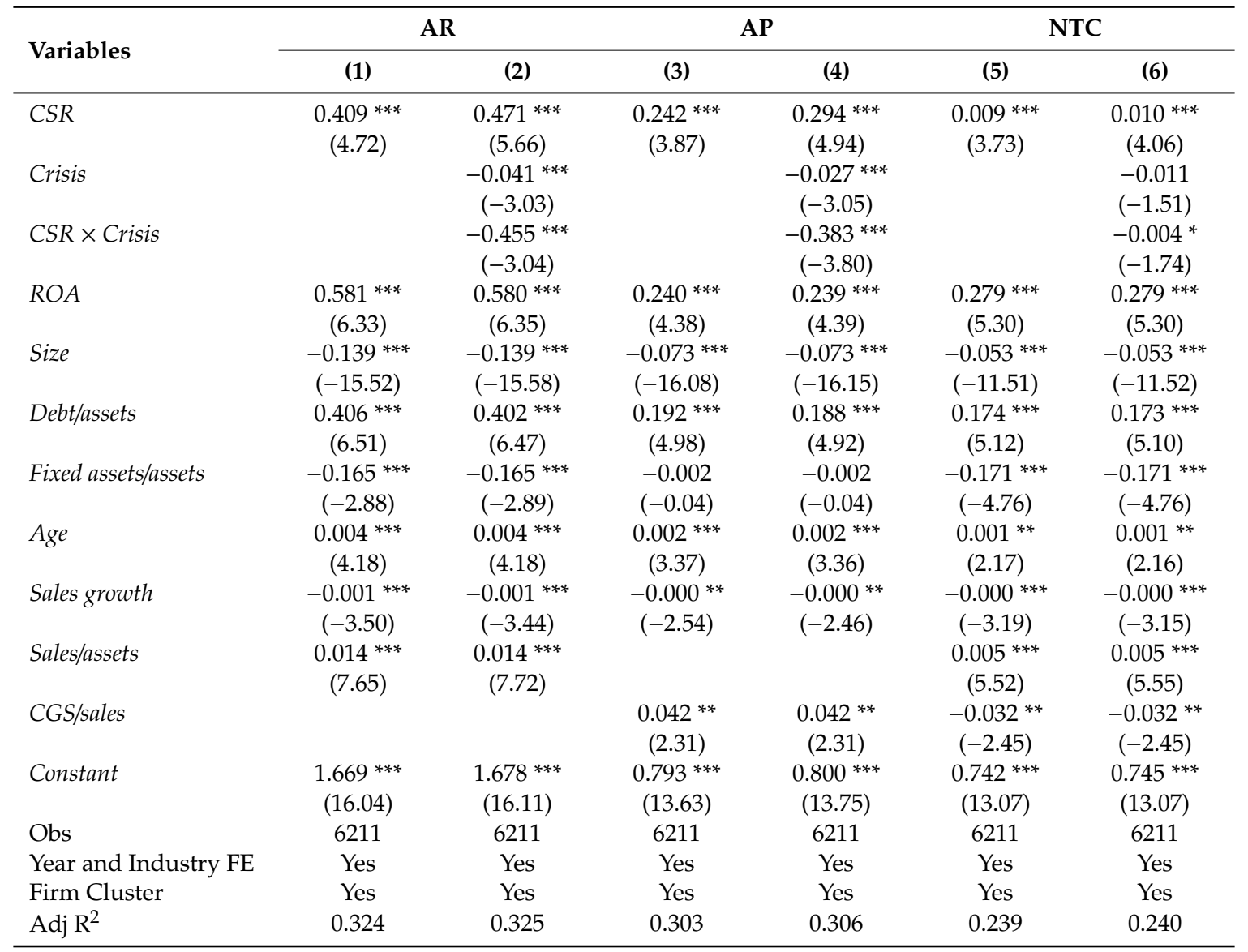

This table report results from regressing trade credit on corporate social responsibility measure and firm controls with other proxies for dependent and independent variables. In Models (1-4), we use an alternative proxy for corporate social responsibility. CSR has calculated the accumulated average of all CSR dimensions that is equal to average strengths minus average concerns in each dimension. In Models (5-6), we use an alternate proxy for trade credit. NTC is the ratio of net trade credit (receivables-payables) to sales. The main sample consists of 6211 firm-year observations from the US manufacturing sector over the 2005-2012 period. Definitions and data sources of all variables are provided in Appendix A. Unreported industry controls are based on the Fama and French 49 industry classification. Robust $\mathrm{t}$-statistics adjusted for clustering by the firm is reported inside the parentheses (Petersen 2009). $* * *$, and ${ }^{* *}$ indicate two-tailed significance at the $10 \%, 5 \%$, and $1 \%$ levels, respectively.

Accounts receivables/sales (AR) and accounts payables/sales (AP) are the most common measures of trade credit (Bougheas et al. 2009; Mateut et al. 2015). However, some prior studies also use the

9 For example, KLD added the support for education strength in community dimension from 1994. Management system strength in environment dimension first awarded in 2006. Indigenous people's relationship strength of community dimension started in 2000 and, in 2002 it moved to the human rights area. 
net trade credit $(N T C=A R-A P)$ as a measure of trade credit (El Ghoul and Zheng 2016; Lin and Chou 2015). It consists of accounts receivables minus accounts payables divided by sales. In Table 5 , Model (5) like previous, CSR shows a positive association with net trade credit. However, in Model 6 crisis loses its significance, while firm-level variables show the same association. On behalf of these results, we say that our results are consistent with alternate proxies of CSR and trade credit.

\subsubsection{Alternate Sample Selection}

In our primary analysis Table 4, we use US manufacturing firms as our sample. Some past studies on trade credit also use all firms (manufacturing and services) or exclude the financial and regulated utility from their final sample (Albuquerque et al. 2015; Goto et al. 2015). Table 6 Models (1 to 4) show the results with all firms' samples and in Models (5 to 8 ) without regulated utility firms for our sample. ${ }^{10}$ In all these cases, CSR performance shows the same significant positive impact on trade credit (buyer and supplier). During the crisis, CSR changes its association with trade credit. All control variables show the same association with trade credit as in Table 4.

Table 6. Sample 2005-2012 with all firms and excluding the regulated utility industry.

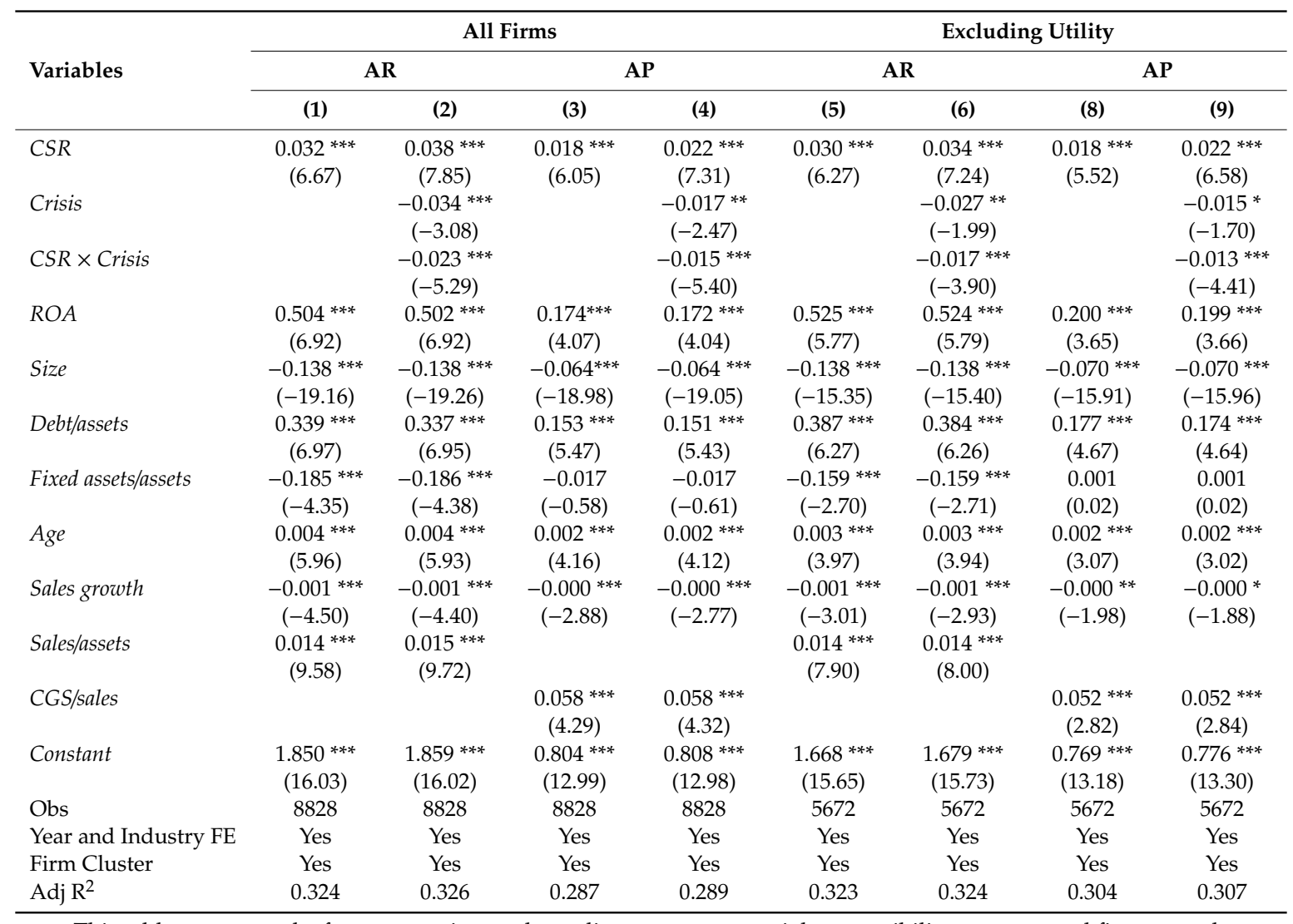

This table report results from regressing trade credit on corporate social responsibility measure and firm controls with a sample period from 2005 to 2012. In Models (1-4), we use all firms, including the services sector from the US in that period. In Models (5-8), we use all manufacturing firms, excluding regulated utility industry $(20<2-$ digit-SIC $>59 \& 2$-digit-SIC $\neq 49$ ) from the US in that period. This table consists of 8828 firm-year observations from the US over the 2005-2012 period. The definitions and data sources of all variables are provided in Appendix A. Unreported industry controls are based on the Fama and French 49 industry classification. Robust $\mathrm{t}-\mathrm{statistics}$ adjusted for clustering by the firm are reported inside the parentheses (Petersen 2009). ${ }^{*},{ }^{* *}$, and ${ }^{* * *}$ indicate two-tailed significance at the $10 \%, 5 \%$, and $1 \%$ levels, respectively.

10 Financial industry was not included in our main sample. 
In our main analysis, we take a sample from 2005 to 2012, to have the same window before and after the crisis. We also test Equation (2) with 2049 firms from 1996 to 2012 in the US. In Table 7, our objective is to verify that a positive relationship between CSR and trade credit exists in the long run. This sample period follows the same procedure as the initial sample.

Table 7. Sample 1996-2012.

\begin{tabular}{|c|c|c|c|c|c|c|}
\hline \multirow{3}{*}{ Variables } & \multicolumn{2}{|c|}{ Manufacturing } & \multicolumn{2}{|c|}{ All Firms } & \multicolumn{2}{|c|}{ Excluding Utility } \\
\hline & AR & AP & AR & AP & AR & AP \\
\hline & (1) & (2) & (3) & (4) & (5) & (6) \\
\hline CSR & $\begin{array}{c}0.024^{* * *} \\
(4.75)\end{array}$ & $\begin{array}{c}0.013^{* * *} \\
(4.34)\end{array}$ & $\begin{array}{c}0.023^{* * * *} \\
(4.93)\end{array}$ & $\begin{array}{c}0.013^{* * *} \\
(4.62)\end{array}$ & $\begin{array}{c}0.027^{* * *} \\
(4.97)\end{array}$ & $\begin{array}{c}0.015^{* * *} \\
(4.57)\end{array}$ \\
\hline$R O A$ & $\begin{array}{c}0.478^{* * *} \\
(5.61)\end{array}$ & $\begin{array}{c}0.194^{* * *} \\
(3.94)\end{array}$ & $\begin{array}{c}0.449 * * * \\
(6.53)\end{array}$ & $\begin{array}{c}0.160^{* * *} \\
(4.03)\end{array}$ & $\begin{array}{c}0.464^{* * *} \\
(5.43)\end{array}$ & $\begin{array}{c}0.185^{* * *} \\
(3.75)\end{array}$ \\
\hline Size & $\begin{array}{c}-0.133^{* * *} \\
(-15.76)\end{array}$ & $\begin{array}{c}-0.070^{* * *} \\
(-16.90)\end{array}$ & $\begin{array}{c}-0.132 * * * \\
(-19.20)\end{array}$ & $\begin{array}{c}-0.064^{* * *} \\
(-19.15)\end{array}$ & $\begin{array}{c}-0.129^{* * * *} \\
(-15.84)\end{array}$ & $\begin{array}{c}-0.068^{* * *} \\
(-17.16)\end{array}$ \\
\hline Debt/assets & $\begin{array}{c}0.365^{* * *} \\
(6.59)\end{array}$ & $\begin{array}{c}0.192 * * * \\
(5.34)\end{array}$ & $\begin{array}{c}0.311^{* * * *} \\
(6.81)\end{array}$ & $\begin{array}{c}0.162^{* * *} \\
(5.78)\end{array}$ & $\begin{array}{c}0.344^{* * *} \\
(6.28)\end{array}$ & $\begin{array}{c}0.180^{* * *} \\
(5.05)\end{array}$ \\
\hline Fixed assets/assets & $\begin{array}{c}-0.191^{* * * *} \\
(-3.82)\end{array}$ & $\begin{array}{l}-0.027 \\
(-0.73)\end{array}$ & $\begin{array}{c}-0.192 * * * \\
(-4.93)\end{array}$ & $\begin{array}{l}-0.026 \\
(-0.96)\end{array}$ & $\begin{array}{c}-0.172^{* * * *} \\
(-3.27)\end{array}$ & $\begin{array}{l}-0.016 \\
(-0.40)\end{array}$ \\
\hline Age & $\begin{array}{c}0.003^{* * *} \\
(3.84)\end{array}$ & $\begin{array}{c}0.002^{* * *} \\
(3.43)\end{array}$ & $\begin{array}{c}0.005^{* * *} \\
(5.86)\end{array}$ & $\begin{array}{c}0.002^{* * *} \\
(4.37)\end{array}$ & $\begin{array}{c}0.003^{* * *} \\
(3.84)\end{array}$ & $\begin{array}{c}0.002^{* * *} \\
(3.48)\end{array}$ \\
\hline Sales growth & $\begin{array}{c}-0.001 \text { *** } \\
(-3.32)\end{array}$ & $\begin{array}{c}-0.000 * * \\
(-2.53)\end{array}$ & $\begin{array}{c}-0.001 * * * \\
(-4.07)\end{array}$ & $\begin{array}{c}-0.000^{* * *} \\
(-2.74)\end{array}$ & $\begin{array}{c}-0.001 \text { **** } \\
(-2.97)\end{array}$ & $\begin{array}{c}-0.000 \text { ** } \\
(-2.17)\end{array}$ \\
\hline Sales/assets & $\begin{array}{c}0.011^{* * *} \\
(6.77)\end{array}$ & & $\begin{array}{c}0.012 * * * \\
(8.48)\end{array}$ & & $\begin{array}{c}0.011^{* * *} \\
(6.64)\end{array}$ & \\
\hline CGS/sales & & $\begin{array}{c}0.044^{* *} \\
(2.48)\end{array}$ & & $\begin{array}{c}0.056^{* * *} \\
(4.22)\end{array}$ & & $\begin{array}{c}0.050^{* * *} \\
(2.75)\end{array}$ \\
\hline Constant & $\begin{array}{c}1.726^{* * *} \\
(16.12)\end{array}$ & $\begin{array}{c}0.834^{* * *} \\
(13.98)\end{array}$ & $\begin{array}{c}1.890^{* * * *} \\
(17.06)\end{array}$ & $\begin{array}{c}0.849^{* * *} \\
(14.24)\end{array}$ & $\begin{array}{c}1.675^{* * *} \\
(15.96)\end{array}$ & $\begin{array}{c}0.793 * * * \\
(13.76)\end{array}$ \\
\hline Obs & 9069 & 9069 & 12,496 & 12,496 & 8227 & 8227 \\
\hline Year and Industry FE & Yes & Yes & Yes & Yes & Yes & Yes \\
\hline Firm Cluster & Yes & Yes & Yes & Yes & Yes & Yes \\
\hline Adj $R^{2}$ & 0.328 & 0.324 & 0.316 & 0.290 & 0.313 & 0.312 \\
\hline
\end{tabular}

This table reports results from regressing trade credit on corporate social responsibility measure and firm controls with a sample period from 1996 to 2012. In Models (1-2), we use all manufacturing firms (20 $\geq 2$-digit-SIC $\leq 59)$ from the US in that period. In Models (3-4), we use all firms from the US in that period. In Models (5-6), we use all manufacturing firms, excluding the regulated utility industry $(20<2$-digit-SIC $>59 \& 2$-digit-SIC $\neq 49)$ from US in that period. This table consists of 12,496 firm-year observations from the US over the 1996-2012 period. Definitions and data sources of all variables are provided in Appendix A. Unreported industry controls are based on the Fama and French 49 industry classification. Robust t-statistics adjusted for clustering by the firm is reported inside the parentheses (Petersen 2009). ${ }^{*}, * *$, and ${ }^{* * *}$ indicate two-tailed significance at the $10 \%, 5 \%$, and $1 \%$ levels, respectively.

In the first two models, we estimate the effect of CSR on trade credit with the manufacturing ${ }^{11}$ industry for the full period from 1996 to 2012 firm. Firms with better social performance tend more trade credit (buyer and supplier), and these results are consistent with our main findings in Table 4 . In Models (3) and (4), we estimate Equation (2) with all firms. CSR is still showing a positive relationship with trade credit with this extended sample and it is consistent with the main results (Zhang et al. 2014). In Models (5) and (6), we test whether this relationship also exists after excluding the regulated utility industry. Consistent with previous findings, CSR shows a significant positive association with trade credit. All control variables show the same association with trade credit as shown in Table 4.

11 Manufacturing firms $(20 \geq 2$-digit-SIC $\leq 59)$ from US in that period. 


\subsubsection{Endogeneity}

Our principal analysis suggests that CSR is positively associated with the buyer and supplier sides of trade credit. However, potential endogeneity may affect the relationship between CSR and trade credit. To mitigate the endogeneity concerns, we use a two-stage least square (2SLS) and difference-in-difference (DID).

First, we use a two-stage least square technique. To use this technique, we must construct good instruments. Instruments are correlated with CSR but uncorrelated with trade credit and an error term, and it only affects trade-credit trough CSR. Following Jiraporn et al. (2014), we use average CSR score close geography firms (same 3-digit ZIP) and average CSR score industry peers (Fama-French 49 industry) as instruments. Table 8 Models (1) and (3) show the results of the first stage regression. Both instruments show a positive relationship with CSR. In Models (2) and (4), we use the CSR instrumented values as an independent variable and estimates the consistency of our results. With instrumented values, CSR still has a positive relationship with trade credit (buyer and supplier). These results show that our results are also consistent with the 2SLS approach. Models (2) and (4), Sargan $p$-values are 0.224 and 0.266 , and show that overidentification restrictions and instruments are valid (Jiraporn et al. 2014).

Table 8. Two-stage least squares estimation.

\begin{tabular}{|c|c|c|c|c|}
\hline \multirow{3}{*}{ Variables } & \multicolumn{2}{|c|}{ AR } & \multicolumn{2}{|c|}{ AP } \\
\hline & 1st Stage & 2nd Stage & 1st Stage & 2nd Stage \\
\hline & (1) & (2) & (3) & (4) \\
\hline CSR & & $\begin{array}{c}0.023^{* * *} \\
(6.64)\end{array}$ & & $\begin{array}{l}0.013^{* * *} \\
(5.38)\end{array}$ \\
\hline $\begin{array}{l}\text { Average CSR score Geography close firm } \\
\text { (3-digit ZIP) }\end{array}$ & $\begin{array}{l}0.897^{* * *} \\
(45.05)\end{array}$ & & $\begin{array}{l}0.903 * * * \\
(45.07)\end{array}$ & \\
\hline $\begin{array}{l}\text { Average CSR score Industry Peer } \\
\text { (Fama-French } 49 \text { Industry) }\end{array}$ & $\begin{array}{l}0.704^{* * *} \\
(13.49)\end{array}$ & & $\begin{array}{c}0.709 * * * \\
(13.52)\end{array}$ & \\
\hline$R O A$ & $\begin{array}{l}1.845^{* * *} \\
(5.67)\end{array}$ & $\begin{array}{l}0.560^{* * *} \\
(9.87)\end{array}$ & $\begin{array}{l}2.241^{* * *} \\
(6.90)\end{array}$ & $\begin{array}{l}0.229 * * * \\
(6.07)\end{array}$ \\
\hline Size & $\begin{array}{c}0.115^{* * *} \\
(6.61)\end{array}$ & $\begin{array}{c}-0.141^{* * *} \\
(-46.16)\end{array}$ & $\begin{array}{l}0.016 \\
(1.16)\end{array}$ & $\begin{array}{c}-0.073^{* * *} \\
(-46.37)\end{array}$ \\
\hline Debt/assets & $\begin{array}{l}-0.039 \\
(-0.23)\end{array}$ & $\begin{array}{c}0.410^{* * *} \\
(13.99)\end{array}$ & $\begin{array}{l}0.181 \\
(1.07)\end{array}$ & $\begin{array}{l}0.194^{* * *} \\
(10.06)\end{array}$ \\
\hline Fixed assets/assets & $\begin{array}{c}0.309 * \\
(1.77)\end{array}$ & $\begin{array}{l}-0.170 * * * \\
(-5.70)\end{array}$ & $\begin{array}{l}0.355^{* *} \\
(2.03)\end{array}$ & $\begin{array}{l}-0.006 \\
(-0.29)\end{array}$ \\
\hline Age & $\begin{array}{l}0.017^{* * * *} \\
(7.81)\end{array}$ & $\begin{array}{l}0.003^{* * *} \\
(9.05)\end{array}$ & $\begin{array}{c}0.022 * * * \\
(10.07)\end{array}$ & $\begin{array}{l}0.002 * * * \\
(7.17)\end{array}$ \\
\hline Sales growth & $\begin{array}{l}-0.005^{* * *} \\
(-3.32)\end{array}$ & $\begin{array}{l}-0.001^{* * *} \\
(-4.07)\end{array}$ & $\begin{array}{l}-0.005^{* * *} \\
(-3.66)\end{array}$ & $\begin{array}{l}-0.000^{* * *} \\
(-2.91)\end{array}$ \\
\hline Sales/assets & $\begin{array}{l}-0.061^{* * *} \\
(-9.16)\end{array}$ & $\begin{array}{l}0.014^{* * *} \\
(12.20)\end{array}$ & & \\
\hline CGS/sales & & & $\begin{array}{l}-0.286^{* * *} \\
(-4.63)\end{array}$ & $\begin{array}{l}0.045^{* * *} \\
(6.32)\end{array}$ \\
\hline Constant & $\begin{array}{l}-1.665 \\
(-0.91)\end{array}$ & $\begin{array}{l}1.691^{* * *} \\
(5.35)\end{array}$ & $\begin{array}{l}-0.538 \\
(-0.29)\end{array}$ & $\begin{array}{l}0.794^{* * *} \\
(3.78)\end{array}$ \\
\hline Obs & 6211 & 6211 & 6211 & 6211 \\
\hline Year and Industry FE & Yes & Yes & Yes & Yes \\
\hline Adj $R^{2}$ & 0.381 & 0.341 & 0.374 & 0.319 \\
\hline Sargan $p$-value & & 0.224 & & 0.266 \\
\hline
\end{tabular}

This table report results with 2SLS regressions of trade credit on corporate social responsibility measure and firm controls. Models (1 and 3) show the results of first-stage regressions. We use Average CSR geography close firms (3-digit ZIP), and Average CSR score form industry (Fama-French 49 Industry). Models (2 and 4 ) show the results of the second stage regressions. The primary sample consists of 6211 firm-year observations from the US manufacturing sector over the 2005-2012 period. Definitions and data sources of all variables are provided in Appendix A. Unreported industry controls are based on the Fama and French 49 industry classification. ${ }^{*}{ }^{* *}$, and ${ }^{* * *}$ indicate two-tailed significance at the $10 \%, 5 \%$, and $1 \%$ levels, respectively. 
In Table 9, we show Difference-in-Difference (DID) regression results. In this Table, our objective is to check if the trade credit policies of the firm are the same before and after the financial crisis (2008-2009) for high and low CSR firms. In Panel A, we use accounts receivables/sales (AR) as the dependent variable, CSR dummy ${ }^{12}$ as a treatment variable, and crisis dummy ${ }^{13}$ as the time variable. In this DID regression, we use data four years before (2005-2008) and four years after (2009-2012) crisis. Empirical findings state that control firms reduce trade credit volume to their buyer, but socially responsible firms (treated firms) provide more trade credit to their buyer. Therefore, before the crisis, the buyer side trade credit (AR) is similar to both control and treated firms but after a crisis, socially responsible firms significantly increase it. Furthermore, these results depict that socially responsible firms increase buyer side trade credit (AR) volume about $7 \%$ after the crisis. The overall increase in trade credit (AR) is due to high CSR firms that give more trade credit than low CSR firms and increase trade credit in response to the crisis. This means that socially responsible firms show more trust in their buyer after the crisis.

Table 9. Difference-in-Difference: Exogenous shock of Crisis.

\begin{tabular}{lccc}
\hline Panel A: Accounts Receivables & & & \\
& Before Crisis & After Crisis & After-Before Crisis \\
\cline { 2 - 4 } Control Firms (Low CSR firms) & 0.171 & 0.156 & -0.016 \\
Treated Firms (High CSR firms) & 0.187 & 0.241 & $0.053^{* * *}$ \\
Treated-Control Firms & 0.016 & $0.085^{* * *}$ & $0.069^{* * *}$ \\
Difference-in-Difference & & & $(3.48)$ \\
Observations & 3032 & 3179 & 0.01 \\
R-square & & & \\
\hline Panel B: Accounts Payables & & & After-Before Crisis \\
\hline & Before Crisis & 0.096 & $-0.017^{*}$ \\
Control Firms (Low CSR firms) & 0.112 & 0.158 & $0.036^{* * *}$ \\
Treated Firms (High CSR firms) & 0.121 & $0.062 * * *$ & \\
Treated-Control Firms & 0.009 & & $0.053^{* * *}$ \\
Difference-in-Difference & & 3179 & $(4.07)$ \\
Observations & 3032 & & 0.01 \\
R-square & & & \\
\hline
\end{tabular}

This table reports the difference-in-difference estimations results by introducing the exogenous shock of the financial crisis of 2008-2009. The dependent variable is Account receivables/sales in Panel A and Accounts payables/sales in Panel B. The main variables of interest are CSR dummy variable equal to 1 , if, in the given year, the firm has CSR more than industry median and Crisis dummy variable equal to 1 , if the year is greater than 2008. The main sample consists of 6211 firm-year observations from the US manufacturing sector over the 2005-2012 period. Definitions and data sources of all variables are provided in Appendix A. ${ }^{* * *}$, and ${ }^{* * *}$ indicate two-tailed significance at the $10 \%, 5 \%$, and $1 \%$ levels, respectively.

In Panel B Table 9, we use accounts payables/sales (AP) as the dependent variable, and for the dummy's settings, we use the same design used in Panel A. The results show that control firms receive less trade credit from their supplier after financial crisis 2008-2009. However, the supplier has more trust in socially responsible firms, and they tend towards 3.6\% more trade credit to their socially responsible customers. We find that the supplier has more trust in socially responsible firms and they have significantly more trade credit (5.3\%) after a crisis compared to less socially responsible firms.

12 CSR dummy value 1, if firm's CSR is higher than industry CSR mean value (following Fama-French 49 industrial classification).

13 Crisis dummy value 1 , if year is greater than 2008 , otherwise zero. 
The overall increase in trade credit (AP) is due to high CSR firms that receive more trade credit than low CSR firms and increase trade credit in response to the crisis.

\section{Additional Analysis}

The analysis above expresses that socially responsible firms have better access to the supplier side of trade credit and extend more trade credit to their supplier. In this connection, we also present additional evidence on the relationship between CSR and trade credit and how the crisis affects this relationship.

\section{Domestic versus MNC's}

When the financial crisis started in 2007, it first affected the US financial sector, and afterward, it affected several other countries, and the US economy is considered as a primary victim of this crisis. Fernandes and Gonenc (2016) find that multinational corporations effectively manage their investment and cash needs with geographically diversified operations. Park et al. (2013) argue that domestic and multinational corporations are not different in their debt maturity structure, the speed of leverage adjustment or choice to issue equity or debt. Therefore, we can say that MNCs are quite similar in their financing policies to domestic firms, but they reduce the systematic risk through diversification.

In Table 10, we divided our sample into two sub-samples (Domestic and MNC). There are different measures presented in the literature for MNCs. Following Park et al. (2013), we define MNCs as those firm-years in which foreign sales are at least $50 \%$ of consolidated sales. ${ }^{14}$ We run the same regressions for both subsamples as used in our main analysis. Models $(1,3,5,7)$ estimations show that CSR has a significant positive association ${ }^{15}$ with trade credit (AR and AP) for both domestic and multinational firms. MNCs with better social performance tends almost double trade credit to their buyers with compare to domestic firms. More importantly, in Models $(2,4)$ crisis shows a significant negative relation with trade credit for domestic firms but MNCs crisis has an insignificant negative association. Indeed, we say that crisis negatively affects the trade credit of domestic firms but has no effect on MNCs. Our results are consistent with diversification arguments and prove that MNCs can diversify systematic risk and thus avoid the negative influence of a crisis (Fernandes and Gonenc 2016). However, on the other hand, CSR and crisis interaction terms show a significant negative relationship with trade credit for both domestic and MNCs. Coefficients show that, during crisis, MNCs with better CSR performance reduces the trade credit volume half in comparison to domestic firms. All other control variables show the same effect as in Table 4.

14 We delete those observations where foreign sales data are not available on Worldscope.

15 Our results are also consistent when we use the alternate threshold to define MNCs (foreign sales $\geq 20 \%$ of consolidated sales; results available upon request). 
Table 10. Domestic vs. multinational corporations (MNCs).

\begin{tabular}{|c|c|c|c|c|c|c|c|c|}
\hline \multirow{3}{*}{ Variables } & \multicolumn{4}{|c|}{ Domestic } & \multicolumn{4}{|c|}{ MNC } \\
\hline & \multicolumn{2}{|c|}{ AR } & \multicolumn{2}{|c|}{ AP } & \multicolumn{2}{|c|}{ AR } & \multicolumn{2}{|c|}{ AP } \\
\hline & (1) & (2) & (3) & (4) & (5) & (6) & (7) & (8) \\
\hline$C S R$ & $\begin{array}{c}0.016^{* * *} \\
(2.93)\end{array}$ & $\begin{array}{c}0.023 * * * \\
(3.89)\end{array}$ & $\begin{array}{c}0.014^{* * *} \\
(3.19)\end{array}$ & $\begin{array}{c}0.019^{* * *} \\
(4.21)\end{array}$ & $\begin{array}{c}0.028^{* * *} \\
(4.56)\end{array}$ & $\begin{array}{c}0.032 * * * \\
(5.29)\end{array}$ & $\begin{array}{c}0.015^{* * *} \\
(3.87)\end{array}$ & $\begin{array}{c}0.017^{* * *} \\
(4.59)\end{array}$ \\
\hline Crisis & & $\begin{array}{c}-0.057^{* *} \\
(-2.42)\end{array}$ & & $\begin{array}{c}-0.047^{* * *} \\
(-2.89)\end{array}$ & & $\begin{array}{l}-0.020 \\
(-0.93)\end{array}$ & & $\begin{array}{l}-0.005 \\
(-0.38)\end{array}$ \\
\hline CSR $\times$ Crisis & & $\begin{array}{c}-0.028 * * * \\
(-3.52)\end{array}$ & & $\begin{array}{c}-0.020 * * * \\
(-3.93)\end{array}$ & & $\begin{array}{c}-0.016^{* * *} \\
(-2.88)\end{array}$ & & $\begin{array}{c}-0.009 * * \\
(-2.49)\end{array}$ \\
\hline$R O A$ & $\begin{array}{l}0.169 \\
(1.46)\end{array}$ & $\begin{array}{l}0.172 \\
(1.49)\end{array}$ & $\begin{array}{l}0.011 \\
(0.14)\end{array}$ & $\begin{array}{l}0.011 \\
(0.14)\end{array}$ & $\begin{array}{c}0.645^{* * *} \\
(4.06)\end{array}$ & $\begin{array}{c}0.641^{* * *} \\
(4.07)\end{array}$ & $\begin{array}{c}0.288^{* * *} \\
(3.16)\end{array}$ & $\begin{array}{c}0.285^{* * *} \\
(3.16)\end{array}$ \\
\hline Size & $\begin{array}{c}-0.144^{* * *} \\
(-9.64)\end{array}$ & $\begin{array}{c}-0.144^{* * *} \\
(-9.75)\end{array}$ & $\begin{array}{c}-0.080 * * * \\
(-10.29)\end{array}$ & $\begin{array}{c}-0.080^{* * *} \\
(-10.39)\end{array}$ & $\begin{array}{c}-0.151 \text { *** } \\
(-12.07)\end{array}$ & $\begin{array}{c}-0.1511^{* * *} \\
(-12.11)\end{array}$ & $\begin{array}{c}-0.076^{* * *} \\
(-12.44)\end{array}$ & $\begin{array}{c}-0.075 * * * \\
(-12.47)\end{array}$ \\
\hline Debt/assets & $\begin{array}{c}0.329 * * * \\
(4.13)\end{array}$ & $\begin{array}{c}0.327^{* * *} \\
(4.14)\end{array}$ & $\begin{array}{c}0.143^{* * *} \\
(2.72)\end{array}$ & $\begin{array}{c}0.141^{* * *} \\
(2.70)\end{array}$ & $\begin{array}{c}0.589 * * * \\
(5.03)\end{array}$ & $\begin{array}{c}0.583 * * * \\
(5.00)\end{array}$ & $\begin{array}{c}0.310^{* * *} \\
(4.51)\end{array}$ & $\begin{array}{c}0.306^{* * *} \\
(4.48)\end{array}$ \\
\hline Fixed assets/assets & $\begin{array}{c}-0.214^{* * *} \\
(-2.83)\end{array}$ & $\begin{array}{c}-0.213^{* * *} \\
(-2.83)\end{array}$ & $\begin{array}{l}0.004 \\
(0.06)\end{array}$ & $\begin{array}{l}0.005 \\
(0.07)\end{array}$ & $\begin{array}{l}-0.134 \\
(-1.26)\end{array}$ & $\begin{array}{l}-0.135 \\
(-1.28)\end{array}$ & $\begin{array}{l}0.004 \\
(0.06)\end{array}$ & $\begin{array}{l}0.004 \\
(0.05)\end{array}$ \\
\hline Age & $\begin{array}{c}0.005^{* * *} \\
(3.69)\end{array}$ & $\begin{array}{c}0.005^{* * *} \\
(3.66)\end{array}$ & $\begin{array}{c}0.003^{* * *} \\
(3.78)\end{array}$ & $\begin{array}{c}0.003^{* * *} \\
(3.74)\end{array}$ & $\begin{array}{c}0.003^{* *} \\
(2.07)\end{array}$ & $\begin{array}{c}0.003^{* *} \\
(2.08)\end{array}$ & $\begin{array}{l}0.001 \\
(0.96)\end{array}$ & $\begin{array}{l}0.001 \\
(0.96)\end{array}$ \\
\hline Sales growth & $\begin{array}{l}-0.001 \\
(-1.22)\end{array}$ & $\begin{array}{l}-0.000 \\
(-1.10)\end{array}$ & $\begin{array}{l}-0.000 \\
(-0.90)\end{array}$ & $\begin{array}{l}-0.000 \\
(-0.77)\end{array}$ & $\begin{array}{c}-0.001 * * \\
(-2.03)\end{array}$ & $\begin{array}{c}-0.001 * \\
(-1.94)\end{array}$ & $\begin{array}{l}-0.000 \\
(-1.33)\end{array}$ & $\begin{array}{l}-0.000 \\
(-1.24)\end{array}$ \\
\hline Sales/assets & $\begin{array}{c}0.018^{* * *} \\
(5.66)\end{array}$ & $\begin{array}{c}0.018^{* * *} \\
(5.78)\end{array}$ & & & $\begin{array}{c}0.015^{* * *} \\
(5.62)\end{array}$ & $\begin{array}{c}0.015^{* * *} \\
(5.70)\end{array}$ & & \\
\hline CGS/sales & & & $\begin{array}{l}0.029 \\
(1.29)\end{array}$ & $\begin{array}{l}0.030 \\
(1.33)\end{array}$ & & & $\begin{array}{c}0.074 \text { ** } \\
(2.41)\end{array}$ & $\begin{array}{c}0.073^{* *} \\
(2.40)\end{array}$ \\
\hline Constant & $\begin{array}{c}1.889 * * * \\
(10.36)\end{array}$ & $\begin{array}{c}1.902 * * * \\
(10.44)\end{array}$ & $\begin{array}{c}1.021^{* * *} \\
(9.66)\end{array}$ & $\begin{array}{c}1.026^{* * *} \\
(9.72)\end{array}$ & $\begin{array}{c}1.895^{* * *} \\
(11.51)\end{array}$ & $\begin{array}{c}1.893 * * * \\
(11.52)\end{array}$ & $\begin{array}{c}0.919 * * * \\
(10.88)\end{array}$ & $\begin{array}{c}0.918^{* * *} \\
(10.87)\end{array}$ \\
\hline Obs & 2317 & 2317 & 2317 & 2317 & 2792 & 2792 & 2792 & 2792 \\
\hline Year \& Industry FE & Yes & Yes & Yes & Yes & Yes & Yes & Yes & Yes \\
\hline Firm Cluster & Yes & Yes & Yes & Yes & Yes & Yes & Yes & Yes \\
\hline Adj $R^{2}$ & 0.356 & 0.360 & 0.333 & 0.338 & 0.380 & 0.381 & 0.380 & 0.381 \\
\hline
\end{tabular}

This table report results from regressing trade credit on corporate social responsibility measure and firm controls on domestic and MNC firms' sample. $A R$ is the ratio of total receivables to total sales; $A P$ is the ratio of total payables to total sales; CSR is calculated as total strengths minus total concerns; Crisis is a dummy variable that takes the value one for the year 2008 and 2009. We divide our sample based on foreign sales. If a firm has foreign sales of more than $50 \%$ of total sales, then it included in the MNC firm's sample otherwise included in domestic firm's sample. The main sample consists of 6211 firm-year observations from the US manufacturing sector over the 2005-2012 period. Definitions and data sources of all variables are provided in Appendix A. Unreported industry controls are based on the Fama and French 49 industry classification. Robust t-statistics adjusted for clustering by the firm is reported inside the parentheses (Petersen 2009). ${ }^{*}, * *$, and ${ }^{* * *}$ indicate two-tailed significance at the $10 \%, 5 \%$ and $1 \%$ levels, respectively.

\section{Conclusions}

In this study, we examine the relationship between CSR and trade credit for the US manufacturing sector. We also check how the financial crisis of 2008-2009 effects this relationship. Using 6211 firm-year observations from US manufacturing industries over the 2005-2012 period, and after controlling firm-level characteristics, we find a positive relationship between CSR and both sides of trade credit (buyer side AR and supplier side AP). Our results align with the notion that firms with CSR-oriented policies have better access to finance and promote better relations with their stakeholders. We also find that the financial crisis of 2008-2009 adversely affects the trade credit, and the positive association vanishes between CSR and trade credit during the crisis. These results robust with alternative proxies for CSR and trade credit, other sample selection and period, and addressing endogeneity concerns through 2SLS and Difference-in-Difference estimation methods. In an additional analysis, we show that this relationship exists for both domestic and multinational firms but during the crisis, domestic firms show a more negative association in comparison to MNCs.

Our results are consistent with several theories of CSR. The first theory that we test with our first hypothesis is that socially responsible firms have easier access to finance (Attig et al. 2013; Goss and Roberts 2011; Jiraporn et al. 2014). The second theory that was proven through our second hypothesis is that socially responsible firms promote a better relationship with their stakeholders through trust 
and stakeholder value maximization goal (Cheng et al. 2014; Choi and Wang 2009; Deng et al. 2013). A third theory is that crisis affects the associations between CSR and firm financial attributes, for which we conjecture the third and fourth hypotheses (Lins et al. 2017; Tsuruta 2015; Wu and Shen 2013).

This study adds to the growing body of the CSR literature in the corporate finance domain. By focusing on trade credit, our empirical findings suggest that management decisions to invest in CSR activities are beneficial to gaining the trust of stakeholders and help the firm to get more financing. A practical limitation of this study is that results are may be different from our findings with a sample of the least crisis-affected countries, because the US economy is profoundly affected during the global financial crisis. For future research, this study opens new avenues for researchers to answer this problem statement in different ethnicity and regional contexts.

Author Contributions: Conceptualization, A.S.; methodology, A.S.; software, A.S.; formal analysis, A.S.; data curation, Q.Z.; writing_-original draft preparation, A.S.; writing-review and editing, A.S. and Q.Z.; project administration, and Q.Z. All authors have read and agreed to the published version of the manuscript.

Funding: This research received no external funding.

Conflicts of Interest: The authors declare no conflict of interest

\section{Appendix A}

Table A1. Definitions and sources of variables.

\begin{tabular}{|c|c|c|}
\hline Variable & Definition & Source \\
\hline \multicolumn{3}{|c|}{ Dependent variables } \\
\hline$A R$ & The ratio of total receivables to total sales. & Worldscope \\
\hline$A P$ & The ratio of total payables to total sales. & Worldscope \\
\hline \multicolumn{3}{|c|}{ Independent variables } \\
\hline CSR & $\begin{array}{l}\text { Corporate social responsibility is calculated as total } \\
\text { strengths minus total concerns in each period. }\end{array}$ & MSCI ESG and authors' calculation \\
\hline Crisis & $\begin{array}{l}\text { Crisis is a dummy variable that takes the value one for } \\
\text { the year } 2008 \text { and } 2009\end{array}$ & Authors' calculation \\
\hline CSR $\times$ Crisis & This variable is an interaction term of CSR and Crisis. & MSCI ESG and authors' calculation \\
\hline \multicolumn{3}{|l|}{ Control variables } \\
\hline$R O A$ & $\begin{array}{l}\text { Return on assets calculated as net income divided by } \\
\text { total assets. }\end{array}$ & Worldscope \\
\hline Size & Size is the natural logarithm of total sales in \$US millions. & Worldscope \\
\hline Debt/assets & Debt/assets is the ratio of long-term debt to total assets. & Worldscope \\
\hline Fixed asset/assets & $\begin{array}{l}\text { Fixed asset/assets is the total of property plant and } \\
\text { equipment scaled by total assets }\end{array}$ & Worldscope \\
\hline Age & Age is the years of experience in year $\mathrm{t}$ & Datastream \\
\hline Sales growth & $\begin{array}{l}\text { Sales growth is the percentage change in the total sales } \\
\text { from the year } t-1 \text { to } t \text {. }\end{array}$ & Worldscope \\
\hline Sales/assets & Sales/assets is the ratio of total sales scaled by total assets. & Worldscope \\
\hline CGS/assets & CGS/assets is the ratio of cost of goods sold to total assets. & Worldscope \\
\hline
\end{tabular}

\section{References}

Adhikari, Binay K. 2016. Causal effect of analyst following on corporate social responsibility. Journal of Corporate Finance 41: 201-16. [CrossRef]

Aktas, Nihat, Eric de Bodt, Frederic Lobez, and Jean-Christophe Statnik. 2012. The information content of trade credit. Journal of Banking and Finance, 361402-13. [CrossRef]

Albuquerque, Rui, Tarun Ramadorai, and Sumudu W. Watugala. 2015. Trade credit and cross-country predictable firm returns. Journal of Financial Economics 115: 592-613. [CrossRef]

Attig, Najah, Sadok El Ghoul, Omrane Guedhami, and Jungwon Suh. 2013. Corporate Social Responsibility and Credit Ratings. Journal of Business Ethics 117: 679-94. [CrossRef]

Bastos, Rafael, and Julio Pindado. 2013. Trade credit during a financial crisis: A panel data analysis. Journal of Business Research 66: 614-20. [CrossRef] 
Becchetti, Leonardo, Rocco Ciciretti, Iftekhar Hasan, and Nada Kobeissi. 2012. Corporate social responsibility and shareholder's value. Journal of Business Research 65: 1628-35. [CrossRef]

Bliss, Barbara A., Yingmei Cheng, and David J. Denis. 2015. Corporate payout, cash retention, and the supply of credit: Evidence from the 2008-2009 credit crisis. Journal of Financial Economics 115: 521-40. [CrossRef]

Boubaker, Sabri, and Duc Khuong Nguyen, eds. 2012. Board Directors and Corporate Social Responsibility. London: Palgrave Macmillan.

Boubaker, Sabri, and Duc Khuong Nguyen. 2014. Corporate Governance and Corporate Social Responsibility: Emerging Markets Focus. Singapore: World Scientific.

Boubaker, Sabri, Lamia Chourou, Darlene Himick, and Samir Saadi. 2017. It's about time! The influence of institutional investment horizon on corporate social responsibility. Thunderbird International Business Review 59: 571-94. [CrossRef]

Boubaker, Sabri, Kaouther Chebbi, and Jocelyn Grira. 2019. Top management inside debt and corporate social responsibility? Evidence from the US. The Quarterly Review of Economics and Finance. in press. [CrossRef]

Boubaker, Sabri, Alexis Cellier, Riadh Manita, and Asif Saeed. 2020. Does corporate social responsibility reduce financial distress risk? Economic Modelling. in press. [CrossRef]

Bougheas, Sprios, Simona Mateut, and Paul Mizen. 2009. Corporate trade credit and inventories: New evidence of a trade-off from accounts payable and receivable. Journal of Banking and Finance 33: 300-7. [CrossRef]

Cai, Li, Jinhua Cui, and Hoje Jo. 2015. Corporate Environmental Responsibility and Firm Risk. Journal of Business Ethics 139: 1-32. [CrossRef]

Cheng, Beiting, Ioannis Ioannou, and George Serafeim. 2014. Corporate social responsibility and access to finance. Strategic Management Journal 35: 1-23. [CrossRef]

Choi, Jaepil, and Heli Wang. 2009. Stakeholder relations and the persistence of corporate financial performance. Strategic Management Journal 30: 895-907. [CrossRef]

Demirguc-Kunt, Asli, and Vojislav Maksimovic. 2001. Firms as Financial Intermediaries: Evidence from Trade Credit Data. Washington, DC: Development Research Group of World Bank.

Deng, Xin, Jun-Koo Kang, and Buen Sin Low. 2013. Corporate social responsibility and stakeholder value maximization: Evidence from mergers. Journal of Financial Economics 110: 87-109. [CrossRef]

El Ghoul, Sadok, and Xiaolan Zheng. 2016. Trade credit provision and national culture. Journal of Corporate Finance 41: 475-501. [CrossRef]

El Ghoul, Sadok, Omrane Guedhami, Chuck C. Y. Kwok, and Dev R. Mishra. 2011. Does corporate social responsibility affect the cost of capital? Journal of Banking and Finance 35: 2388-406. [CrossRef]

Elfenbein, Daniel W., Ray Fisman, and Brain McManus. 2012. Charity as a Substitute for Reputation: Evidence from an Online Marketplace. The Review of Economic Studies 79: 1441-68. [CrossRef]

Fafchamps, Marcel. 1997. Trade credit in Zimbabwean manufacturing. World Development 25: 795-815. [CrossRef]

Fernandes, Nuno, and Halit Gonenc. 2016. Multinationals and cash holdings. Journal of Corporate Finance 39: 139-54. [CrossRef]

Ferrando, Annalisa, and Klaas Mulier. 2013. Do firms use the trade credit channel to manage growth? Journal of Banking and Finance 37: 3035-46. [CrossRef]

Ferris, J. Stephen. 1981. A Transactions Theory of Trade Credit Use. The Quarterly Journal of Economics 96: 243-70. [CrossRef]

Fisman, Raymond, and Mayank Raturi. 2004. Does Competition Encourage Credit Provision? Evidence from African Trade Credit Relationships. The Review of Economics and Statistics 86: 345-52. [CrossRef]

Giannetti, Mariassunta, Mike Burkart, and Tore Ellingsen. 2011. What You Sell Is What You Lend? Explaining Trade Credit Contracts. The Review of Financial Studies 24: 1261-98. [CrossRef]

Goss, Allen, and Gordon S. Roberts. 2011. The impact of corporate social responsibility on the cost of bank loans. Journal of Banking and Finance 35: 1794-810. [CrossRef]

Goto, Shingo, Gang Xiao, and Yan Xu. 2015. As told by the supplier: Trade credit and the cross section of stock returns. Journal of Banking and Finance 60: 296-309. [CrossRef]

Harjoto, Maretno, and Indrarini Laksmana. 2016. The Impact of Corporate Social Responsibility on Risk Taking and Firm Value. Journal of Business Ethics 151: 353-73. [CrossRef]

Herremans, Irene M., Parporn Akathaporn, and M. McInnes. 1993. An investigation of corporate social responsibility reputation and economic performance. Accounting, Organizations and Society 18: 587-604. [CrossRef] 
Jiraporn, Pornsit, Napatsorn Jiraporn, Adisak Boeprasert, and Kiyoung Chang. 2014. Does Corporate Social Responsibility (CSR) Improve Credit Ratings? Evidence from Geographic Identification. Financial Management 43: 505-31. [CrossRef]

Jo, Hoje, and Haejung Na. 2012. Does CSR Reduce Firm Risk? Evidence from Controversial Industry Sectors. Journal of Business Ethics 110: 441-56. [CrossRef]

Kempf, Alexander, and Peer Osthoff. 2007. The Effect of Socially Responsible Investing on Portfolio Performance. European Financial Management 13: 908-22. [CrossRef]

Kim, Yongtae, Haidan Li, and Siqi Li. 2014. Corporate social responsibility and stock price crash risk. Journal of Banking and Finance 43: 1-13. [CrossRef]

Lee, Darren D., and Robert W. Faff. 2009. Corporate Sustainability Performance and Idiosyncratic Risk: A Global Perspective. Financial Review 44: 213-37. [CrossRef]

Lin, Tsung-Te, and Jian-Hsin Chou. 2015. Trade credit and bank loan: Evidence from Chinese firms. International Review of Economics \& Finance 36: 17-29.

Lins, Karl V., Henri Servaes, and Ane Tamayo. 2017. Social Capital, Trust, and Firm Performance: The Value of Corporate Social Responsibility during the Financial Crisis. The Journal of Finance 72: 1785-824. [CrossRef]

Liu, Xiaoding, and Jay R. Ritter. 2011. Local underwriter oligopolies and IPO underpricing. Journal of Financial Economics 102: 579-601. [CrossRef]

Love, Inessa, Lorenzo A. Preve, and Virginia Sarria-Allende. 2007. Trade credit and bank credit: Evidence from recent financial crises. Journal of Financial Economics 83: 453-69. [CrossRef]

Manescu, Cristiana. 2011. Stock returns in relation to environmental, social and governance performance: Mispricing or compensation for risk? Sustainable Development 19: 95-118. [CrossRef]

Margolis, Joshua D., and Jjames P. Walsh. 2003. Misery Loves Companies: Rethinking Social Initiatives by Business. Administrative Science Quarterly 48: 268-305. [CrossRef]

Margolis, Joshua D., Hillary Anger Elfenbein, and James P. Walsh. 2009. Does It Pay to Be Good... and Does It Matter? A Meta-Analysis of the Relationship between Corporate Social and Financial Performance. Working Paper. Available online: https://papers.ssrn.com/sol3/papers.cfm?abstract_id=1866371 (accessed on 2 July 2020).

Mateut, Simona, Paul Mizen, and Ydriss Ziane. 2015. Inventory composition and trade credit. International Review of Financial Analysis 42: 434-46. [CrossRef]

McMillan, John, and Christopher Woodruff. 1999. Interfirm Relationships and Informal Credit in Vietnam. The Quarterly Journal of Economics 114: 1285-320. [CrossRef]

$\mathrm{Ng}$, Cchee K., Janet Kiholm Smith, and Richard L. Smith. 1999. Evidence on the Determinants of Credit Terms Used in Interfirm Trade. The Journal of Finance 54: 1109-29. [CrossRef]

Park, Soon Hong, Jungwon Suh, and Bernard Yeung. 2013. Do multinational and domestic corporations differ in their leverage policies? Journal of Corporate Finance 20: 115-39. [CrossRef]

Petersen, Mitchell A. 2009. Estimating standard errors in finance panel data sets: Comparing approaches. The Review of Financial Studies 22: 435-80. [CrossRef]

Servaes, Henri, and Ane Tamayo. 2013. The Impact of Corporate Social Responsibility on Firm Value: The Role of Customer Awareness. Management Science 59: 1045-61. [CrossRef]

Sharfman, Mark P., and Chitru S. Fernando. 2008. Environmental risk management and the cost of capital. Strategic Management Journal 29: 569-92. [CrossRef]

Statman, Meir, and Denys Glushkov. 2009. The wages of social responsibility. Financial Analysts Journal 65: 33-46. [CrossRef]

Sun, Wenbin, and Kexiu Cui. 2014. Linking corporate social responsibility to firm default risk. European Management Journal 32: 275-87. [CrossRef]

Tsuruta, Daisuke. 2015. Bank loan availability and trade credit for small businesses during the financial crisis. The Quarterly Review of Economics and Finance 55: 40-52. [CrossRef]

Vazquez, Francisco, and Pablo Federico. 2015. Bank funding structures and risk: Evidence from the global financial crisis. Journal of Banking and Finance 61: 1-14. [CrossRef]

$\mathrm{Wu}$, Meng-Wen, and Chung-Hua Shen. 2013. Corporate social responsibility in the banking industry: Motives and financial performance. Journal of Banking and Finance 37: 3529-47. [CrossRef]

Wu, Wenfeng, Michael Firth, and Oliver M. Rui. 2014. Trust and the provision of trade credit. Journal of Banking and Finance 39: 146-59. [CrossRef] 
Wu, Meng-Wen, Chung-Hua Shen, and Ting-Hsuan Chen. 2017. Application of multi-level matching between financial performance and corporate social responsibility in the banking industry. Review of Quantitative Finance and Accounting 49: 29-63. [CrossRef]

Zhang, Min, Lijun Ma, Jun Su, and Wen Zhang. 2014. Do Suppliers Applaud Corporate Social Performance? Journal of Business Ethics 121: 543-57. [CrossRef] 